\title{
Evaluation of mahua oil cake (Bassia latifolia Roxb.) as a non-conventional feed ingredient for Labeo rohita (Ham.) fingerlings
}

\author{
S. C. RATH, K. C. NAYAK, T. K. MOHANTY, C. DEVARAJ, N. K. CHANDAN, \\ K. N. MOHANTA AND S. S. GIRI \\ ICAR-Central Institute of Freshwater Aquaculture, Bhubaneswar - 751 002, Odisha, India \\ e-mail: scrathcifa@yahoo.com
}

\begin{abstract}
Mahua (Bassia latifolia Roxb.) oil cake (MOC) is rich in protein (24\%) and energy (19.0 $\left.\mathrm{KJ} \mathrm{g}^{-1}\right)$ with high levels of fatty acids comprising saturates $(45 \%)$, monoenes $(42 \%)$ and polyunsaturated fatty acids (PUFA, $n-6)(7 \%)$. Saponin, phenol and flavonoids are the main metabolites. Labeo rohita (Hamilton, 1822) fingerlings $(5.25 \pm 0.2 \mathrm{~g})$ were fed with five iso-nitrogenous $(28 \% \mathrm{CP})$ diets containing MOC at $0 \%(\mathrm{~F} 1), 10 \%(\mathrm{~F} 2), 20 \%(\mathrm{~F} 3), 30 \%(\mathrm{~F} 4)$ and $40 \%(\mathrm{~F} 5)$ for 90 days in 3001 cement cisterns. Survival $(\%)$ of all groups were statistically similar ( $>0.05)$. Weight gain (\%) and specific growth rate (SGR) were significantly lower in F1, F2, F5 and higher in F3 and F4 groups ( $<<0.05$ ). Feed conversion ratio (FCR) was significantly lower $(\mathrm{p}<0.05)$ in F4 as compared to the other groups. Among all the dietary treatments, significantly higher $(\mathrm{p}<0.05)$ protein efficiency ratio $(\mathrm{PER})$ and net protein utilisation (NPU) were found in F4. Whole body protein and lipid was significantly higher $(\mathrm{p}<0.05)$ in F4 and F3, respectively. Hemoglobin, glucose, protein and cholesterol in blood were found to be at higher levels in F4 group. All these parameters declined, but serum glutamic oxaloacetic transaminase (SGOT) and serum glutamic pyruvic transaminase (SGPT) levels increased significantly $(\mathrm{p}<0.05)$ in F5. The findings of the study clearly indicated that MOC can be incorporated at $300 \mathrm{~g} \mathrm{~kg}^{-1}$ in the diet of $L$. rohita fingerlings without any adverse effect on growth, survival and nutrient utilisation.
\end{abstract}

Keywords: Fish feed, Mahua oil cake, Non-conventional ingredient

\section{Introduction}

Feed is the most crucial input that greatly influences the productivity and profitability in aquaculture. Reduction in feed cost and mechanisms that triggers nutrient efficiency would increase the net income in aquaculture. Competition for the conventional feed ingredients among livestock, poultry and aquaculture industries is becoming more severe and has tremendous impact on the market dynamics of aquaculture. Fish require more protein in their diet than the land animals and hence aquafeed demands more protein rich ingredients (Hasan et al., 2007). Soybean meal and groundnut oil cake (GNOC) are the major plant proteins used in compounded aquafeeds, followed by other oil cakes (Barman and Karim, 2007; Manomaitis, 2009). Incorporation of soybean meal or cakes of edible oil seeds is becoming too competitive and costly, especially for carp culture. It is, therefore, necessary to search non-conventional plant resources for formulating cost effective carp feeds (FAO, 2010; Lenka et al., 2010; Rath et al., 2014; Daniel, 2016). Bassia latifolia, commonly known as mahua, belongs to Sapotaceae family, grows luxuriantly in the subtropical region of the Indian subcontinent (Jayasree et al., 1998). As a forest product, mahua seed is collected in the unorganised livelihood sector, by tribals in India (Kulkarni et al., 2013; Mishra and Pradhan, 2013; Verma et al., 2014). The seed contains about $40 \%$ fat in the form of oil, mostly used in soap industry and the oil cake (expeller) is generally used as manure for horticultural crops (Ramadan et al., 2016). According to Feedpedia (2016), the potential mahua oil cake (MOC) production in India is estimated at over 150 million $t$ per year. Mahua oil cake is a good piscicide at $250 \mathrm{ppm}$ due to presence of the metabolite saponin (mowrin) which is used to eradicate unwanted and predatory fishes during initial pond preparation in aquaculture. Saponin in the recommended concentration when absorbed through gill or mucus membrane causes hemolysis in fish (Dash et al., 2013). Apart from its toxic principle, MOC is rich in macro and micro nutrients, which is not utilised rationally in the animal feed sector (Singh and Singh, 1991; Ramadan et al., 2016). Very limited information is available on the use of MOC in the feed of livestock animals (Singh et al., 2011; Patil et al., 2013; Jacob et al., 2014; 2015). No published information is available so far on incorporation of MOC in fish feed. Therefore, the present investigation was carried out with the objective of evaluating MOC as a non-conventional ingredient in carp feed. 


\section{Materials and methods}

\section{Feed, fish and experimental set up}

Mahua oil cake was collected from the local oil mill and analysed for its chemical composition in the National fish feed testing laboratory of ICAR-Central Institute of Freshwater Aquaculture (ICAR-CIFA) Bhubaneswar, India. MOC and other conventional ingredients such as GNOC and rice bran were milled to obtain powder. Five iso-nitrogenus $(28 \%$ crude protein, $\mathrm{CP}$ ) feeds were formulated incorporating raw MOC meal at 0\% (F1), 10\% (F2), 20\% (F3), 30\% (F4) and 40\% (F5) along with GNOC, rice bran (RB) and vitamin and mineral premix (Supplevite-M, Jeco Vet Chem Pvt. Ltd, India) as co-ingredients (Table 2). Feed pellets of $2 \mathrm{~mm}$ were made with portable mechanical pelletiser and oven dried at $60^{\circ} \mathrm{C}$. Pellets were crumbled to $0.5 \mathrm{~mm}$ size and stored in airtight plastic containers at room temperature.

The experiment was conducted at the wet laboratory facility of ICAR-CIFA, Bhubaneswar, India during September-December, 2014. Fifteen flow through cement tanks (300 1) with a flow rate of $0.51 \mathrm{~min}^{-1}$ were used for rearing the fish. L. rohita fingerlings $(5.25 \pm 0.2 \mathrm{~g})$ were stocked in 15 tanks@12 no. per tank. Fish were fed ad libitum, twice daily at 0900 and $1600 \mathrm{hrs}$ with the experimental diets (each diet in triplicate tanks), for 90 days with provision of continuous aeration. The unconsumed feed was siphoned out after $2 \mathrm{~h}$ of feeding, dried and weighed to calculate the daily feed intake. Fish were weighed at monthly intervals. Routine water quality parameters viz., temperature, transparency, total alkalinity, hardness, un-ionised ammonia, dissolved oxygen and pH were monitored twice a week as per APHA (1989). Proximate composition of ingredients as well as of the test feeds and initial and final carcass composition were determined. On termination of the experiment, blood was drawn from 10 fish from each dietary group by caudal vein puncture. A fraction of blood was collected in heparinised vial for whole blood hemoglobin assay and the rest was allowed to clot in normal vial for serum collection. The serum was separated by centrifugation ( $5000 \mathrm{rpm}, 5 \mathrm{~min}$ ). The whole blood hemoglobin was analysed immediately and serum was pooled treatment-wise and stored at $-20^{\circ} \mathrm{C}$ for further analysis.

\section{Proximate analysis}

The proximate composition of MOC, experimental diets and whole body composition of the fish was determined according to AOAC (1990). Dry matter was estimated after drying the samples at $105^{\circ} \mathrm{C}$ for $24 \mathrm{~h}$. Crude protein (CP) was determined by Kjeldahl method (Nx6.25) and ether extract (EE) by Soxhlet method using petroleum ether (boiling point $60-80^{\circ} \mathrm{C}$ ). Ash content was analysed following ignition of the sample at $550^{\circ} \mathrm{C}$ in a muffle furnace for $3 \mathrm{~h}$. Fiber content of the feed was determined using Fibertech and gross energy using Bomb caloriemeter (IKA Caloriemeter system, C5000 control).

\section{Fatty acid analysis}

Fatty acid composition of MOC was analysed. Lipids from the samples were extracted by adding $(2: 1 \mathrm{v} / \mathrm{v})$ chloroform-methanol mixture containing $0.01 \%$ butylated hydroxytoluene (BHT) (Folch et al., 1957). The weight of lipids was determined gravimetrically after evaporation of the solvent. Fatty acid methyl esters (FAME) were prepared by acid-catalysed transesterification of total lipids (Christie, 1982). Fatty acid methyl esters were separated by a gas chromatograph equipped with a flame-ionisation detector (Shimadzu GC-2010, Kyoto, Japan) on a DB- 25 capillary column (20 m×0.10 mm I.D., $0.10 \mu \mathrm{m} J \&$ W Scientific, Santa Clara, CA, USA). The fatty acids were identified using fatty acid methyl ester (FAME) standards. Percentage of the normalised area values of fatty acids were taken as weight percentage.

\section{Screening for secondary metabolites}

Aqueous and n-hexane extract of MOC, GNOC and rice bran was prepared and screened for major secondary metabolites viz., tannin, phenol, saponin, alkaloids, glycosides and flavonoids as described by Evans (2000) and Harbone (1998).

\section{Hematological analysis}

Blood samples were analysed for hemoglobin, total protein, albumin, triglyceride, cholesterol, serum glutamic oxaloacetic transaminase (SGOT) and serum glutamic pyruvic transaminase (SGPT) using Greiner diagnostic kits (Bahlingen, Germany) as per the manufaturer's protocols. Globulin was calculated as: Globulin $\left(\mathrm{g} \mathrm{dl}^{-1}\right)=$ total protein $\left(\mathrm{g} \mathrm{dl}^{-1}\right)-\operatorname{albumin}\left(\mathrm{g} \mathrm{dl}^{-1}\right)$

\section{Growth, nutritional indices and survival rate}

Fish were weighed at monthly intervals to ascertain the growth parameters during the experimental period of 90 days. The weight gain (\%), specific growth rate (SGR), feed conversion ratio (FCR), protein efficiency ratio (PER), net protein utilisation (NPU) and survival rate (\%) were calculated as mentioned below.

$$
\begin{array}{ll}
\text { Weight gain }(\%) & =\frac{\text { Final weight }- \text { Initial weight }}{\text { Initial weight }} \times 100 \\
(\mathrm{SGR}) & =\frac{\text { In final weight }- \text { In initial weight }}{\text { Days of experiment }} \times 100 \\
\text { FCR } & =\frac{\text { Feed consumed (dry weight) }}{\text { Live weight gain (wet weight) }}
\end{array}
$$


PER

$=\frac{\text { Live weight gain }}{\text { Protein consumed }}$

NPU $(\%)$

$=\frac{\text { Protein gain in carcass }}{\text { Protein intake in food }} \times 100$

Survival rate $(\%)$

$=\frac{\text { Initial no. of larvae - Final no.of fry }}{\text { Initial no. of larvae }} \times 100$

Statistical analysis

Data were analysed using one-way ANOVA (Snedecor and Cochran, 1967) and the difference between means was tested using Duncan's multiple range test (Duncan, 1955).

\section{Results}

The mean water quality parameters recorded in the experimental tanks during the feeding trial were: temperature $25-26^{\circ} \mathrm{C}$; transparency $27-28 \mathrm{~cm}$; total alkalinity $\left(\mathrm{CaCO}_{3}\right)$ 90-100 $\mathrm{mg} \mathrm{l}^{-1}$; hardness 80-92 $\mathrm{mg} \mathrm{l}^{-1}$; unionised ammonia $<0.1 \mathrm{mg} \mathrm{l}^{-1}$; dissolved oxygen 5-7 $\mathrm{mg} \mathrm{l}^{-1}$ and $\mathrm{pH}$ 7.5-8.5. Chemical composition of all the ingredients is presented in Table 1 and that of the test feeds (F1-F5) is given in Table 2. The feeds were iso-nitrogenous with $280 \mathrm{~g}$ protein $\mathrm{kg}^{-1}$. MOC was incorporated in the experimental feeds by replacing

Table 1. Chemical composition of mahua oil cake, groundnut oil cake and rice bran ( $\mathrm{g} \mathrm{kg}^{-1}$ dry matter basis)

\begin{tabular}{llll}
\hline Parameters & Mahua oil cake & Groundnut oil cake & Rice bran \\
\hline Moisture & $92.2 \pm 0.56$ & $78.6 \pm 0.62$ & $86 \pm 0.48$ \\
Crude protein & $234.9 \pm 0.62$ & $421.6 \pm 0.84$ & $122.6 \pm 0.66$ \\
Crude lipid & $94.4 \pm 0.55$ & $69.8 \pm 0.44$ & $136.3 \pm 0.82$ \\
Crude fiber & $86.0 \pm 0.11$ & $54.2 \pm 0.46$ & $94.4 \pm 0.88$ \\
Ash & $62.3 \pm 0.25$ & $63.6 \pm 0.68$ & $68.8 \pm 0.44$ \\
Nitrogen free extract (NFE) & $522.4 \pm 0.39$ & $390.8 \pm 0.42$ & $577.9 \pm 0.48$ \\
Phytochemicals & & & + \\
Saponin & ++++ & - & ++ \\
Phenol & +++ & + & + \\
Tannin & ++ & + & + \\
Flavonoid & +++ & + & - \\
Alkaloid & + & - & + \\
Glycoside & ++ & & $22.16 \pm 1.46$ \\
Fatty acids (\%) & & $18.58 \pm 1.32$ & $37.39 \pm 1.68$ \\
$\sum$ SFA & $45.07 \pm 1.72$ & $45.22 \pm 1.88$ & $33.18 \pm 1.82$ \\
$\sum$ MUFA & $42.39 \pm 0.23$ & $32.41 \pm 0.86$ & $2.64 \pm 0.64$ \\
$\sum$ PUFA n-6 & $6.72 \pm 0.11$ & $0.58 \pm 0.04$ & $95.37 \pm 1.62$ \\
\hline PUUFA n-3 & $0.63 \pm 0.08$ & $96.79 \pm 1.44$ & \\
Total & $94.81 \pm 1.28$ & & \\
\hline
\end{tabular}

SFA: Saturated fatty acids, MUFA: Monounsaturated fatty acids, PUFA: Polyunsaturated fatty acids

+ detected, ++ moderately detected, +++ adequately detected ++++ strongly detected, - not detected

Table 2. Composition of the mahua oil cake incorporated test diets used for feeding L. rohita fingerlings ( $\mathrm{g} \mathrm{kg}^{-1} \mathrm{dry}_{\text {matter basis) }}$

\begin{tabular}{llllll}
\hline Ingredients & \multicolumn{5}{c}{ Diets } \\
\cline { 2 - 6 } & F1 $(0 \%$ MOC $)$ & F2 $(10 \%$ MOC $)$ & F3 $(20 \%$ MOC $)$ & F4 (30\% MOC) & F5 (40\% MOC) \\
\hline Mahua oil cake & 0 & 100 & 200 & 300 & 400 \\
Groundnut oil cake & 490 & 440 & 410 & 370 & 330 \\
Rice bran & 490 & 440 & 370 & 310 & 250 \\
Vitamin-mineral pre-mix & 20 & 20 & 20 & 20 & 20 \\
\hline Chemical composition & & & & $283.8 \pm 0.64^{\mathrm{a}}$ & $284.1 \pm 0.42^{\mathrm{a}}$ \\
\hline Crude protein & $283.1 \pm 0.52^{\mathrm{a}}$ & $283.7 \pm 1.00^{\mathrm{a}}$ & $284.5 \pm 0.24^{\mathrm{a}}$ & $88.5 \pm 0.12^{\mathrm{d}}$ & $89.7 \pm 0.12^{\mathrm{e}}$ \\
Ether extract & $74.5 \pm 0.24^{\mathrm{a}}$ & $81.6 \pm 0.22^{\mathrm{b}}$ & $84.3 \pm 0.16^{\mathrm{c}}$ & $88.1 \pm 0.14^{\mathrm{d}}$ & $89.3 \pm 0.14^{\mathrm{d}}$ \\
Crude fibre & $71.1 \pm 4.48^{\mathrm{a}}$ & $81.9 \pm 0.24^{\mathrm{b}}$ & $85.8 \pm 0.14^{\mathrm{c}}$ & $67.0 \pm 0.16^{\mathrm{a}}$ & $65.6 \pm 0.34^{\mathrm{a}}$ \\
Ash & $68.7 \pm 0.86^{\mathrm{a}}$ & $69.9 \pm 0.92^{\mathrm{a}}$ & $69.0 \pm 0.62^{\mathrm{a}}$ & $472.5 \pm 0.44^{\mathrm{a}}$ & $471.3 \pm 0.62^{\mathrm{a}}$
\end{tabular}

"Supplevite-M (Jeco Vet Chem Pvt. Ltd, Mumbai, India). Each $1 \mathrm{~kg}$ of Supplevite-M contains: Vitamin A 200000 IU, Vitamin D 40000 IU, Vitamin B 0.8 g, Vitamin E 300 IU, Vitamin K 400 g, Calcium panthonate 1 g, Nicotinamide 4 g, Vitamin B $2.4 \mathrm{mg}$, Choline chloride $60 \mathrm{~g}$, Calcium $300 \mathrm{~g}$, Manganese $11 \mathrm{~g}$, Iodine $0.4 \mathrm{~g}$, Iron 3. g, Zinc $6 \mathrm{~g}$, Copper $0.8 \mathrm{~g}$, Cobalt $0.18 \mathrm{~g}$

The data are mean $\pm \mathrm{SE}$ : Means bearing different superscripts in a row differ significantly $(\mathrm{p}<0.05)$ 
GNOC at 50, 80, 120 and $160 \mathrm{~g}$ and rice bran at 50, 120, 180 and $240 \mathrm{~g}$ per kg of F2, F3, F4 and F5 feeds, respectively. Whole body composition and the growth indices along with survival rate of $L$. rohita fingerlings under different treatments are presented in Tables 3 and 4 , respectively. At $0,10,20,30$ and $40 \%$ inclusion levels of MOC (F1-F5) survival rate did not differ significantly $(p>0.05)$. Among all the dietary treatments, significantly higher $(\mathrm{p}<0.05)$ SGR $\left(\%\right.$ day $\left.^{-1}\right)$ was found in F4 $(30 \%$ MOC inclusion level), whereas it was similar $(\mathrm{p}>0.05)$ in F1 (10\% MOC), F2 (20\% MOC) and F5 (40\% MOC). The FCR was significantly lower $(p<0.05)$ in $F 4$, than fish fed other diets. Similar to SGR, PER and NPU were also significantly higher $(\mathrm{p}<0.05)$ in $\mathrm{F} 4$ among all the dietary treatments (Table 4). The final whole body protein content was maximum in F4 and it was significantly $(\mathrm{p}<0.05)$ higher than the other MOC incorporated diet fed groups. Although there was an increase in whole body ether extract as compared to the initial value, the increase was not proportional to the increase in MOC level in the diets. The final whole body ash content differed significantly $(p<0.05)$ and it showed an increasing trend from F1 to F5 (Table 3). Hemoglobin, total protein and globulin, glucose and cholesterol were significantly higher $(p<0.05)$ in F4 group, and all these parameters declined in the F5 group (Table 5). No significant ( $\mathrm{p}>0.05$ ) difference was observed in triglyceride levels among the different dietary treatments. There was no significant difference $(p>0.05)$ in

Table 3. Whole body composition of $L$. rohita fingerling fed test feeds containing different levels of mahua oil cake for 90 days ( $\mathrm{g} \mathrm{kg}^{-1}$ dry matter basis)

\begin{tabular}{lllllll}
\hline \multirow{2}{*}{ Parameters } & \multirow{2}{*}{ Initial } & \multicolumn{5}{c}{ Diets } \\
\cline { 2 - 6 } & & F1 $(0 \%$ MOC $)$ & F2 $(10 \%$ MOC $)$ & F3 (20\% MOC) & F4 (30\% MOC) & F5 (40\% MOC) \\
\hline Moisture & $786.1 \pm 0.32$ & $772.4 \pm 0.24^{\mathrm{c}}$ & $761.5 \pm 0.33^{\mathrm{a}}$ & $761.7 \pm 0.36^{\mathrm{a}}$ & $768.5 \pm 0.2^{\mathrm{b}}$ & $773.5 \pm 0.16^{\mathrm{d}}$ \\
Crude protein & $615.5 \pm 0.24$ & $629.6 \pm 0.026^{\mathrm{a}}$ & $632.7 \pm 0.24^{\mathrm{c}}$ & $631.3 \pm .0 .82^{\mathrm{b}}$ & $644.2 \pm 0.16^{\mathrm{d}}$ & $633.2 \pm 0.24^{\mathrm{c}}$ \\
Ether extract & $137.5 \pm 0.22$ & $173.6 \pm 0.22^{\mathrm{b}}$ & $187.6 \pm 0.16^{\mathrm{d}}$ & $189.3 \pm 0.25^{\mathrm{e}}$ & $180.6 \pm 0.24^{\mathrm{c}}$ & $166.2 \pm 0.45^{\mathrm{a}}$ \\
Ash & $218.8 \pm 0.26$ & $162.6 \pm 0.23^{\mathrm{a}}$ & $163.5 \pm 0.25^{\mathrm{b}}$ & $164.7 \pm 0.23^{\mathrm{c}}$ & $170.2 \pm 0.13^{\mathrm{d}}$ & $177.4 \pm 0.22^{\mathrm{e}}$ \\
\hline
\end{tabular}

The data are mean $\pm \mathrm{SE}$

Values bearing different superscripts in a row differ significantly $(\mathrm{p}<0.05)$

Table 4. Survival, growth and nutritional indices of $L$. rohita fingerlings fed feeds containing different levels of mahua oil cake

\begin{tabular}{llllll}
\hline Parameter & \multicolumn{4}{c}{ Diets } \\
\cline { 2 - 6 } & F1 $(0 \%$ MOC $)$ & F2 $(10 \%$ MOC $)$ & F3 $(20 \%$ MOC $)$ & F4 (30\% MOC) & F5 (40\% MOC) \\
\hline Survival (\%) & 97.2 & 100 & 100 & 97.2 & 97.2 \\
Weight gain (g) & $4.75 \pm 0.30^{\mathrm{a}}$ & $4.92 \pm 0.41^{\mathrm{a}}$ & $6.08 \pm 0.04^{\mathrm{b}}$ & $8.44 \pm 0.08^{\mathrm{c}}$ & $4.95 \pm 0.21^{\mathrm{a}}$ \\
Weight gain (\%) & $90.59 \pm 5.90^{\mathrm{a}}$ & $93.83 \pm 7.90^{\mathrm{a}}$ & $114.12 \pm 2.3^{\mathrm{b}}$ & $160.75 \pm 1.61^{\mathrm{c}}$ & $94.34 \pm 4.01^{\mathrm{a}}$ \\
SGR (\% day $\left.{ }^{-1}\right)$ & $0.72 \pm 0.034^{\mathrm{a}}$ & $0.73 \pm 0.046^{\mathrm{a}}$ & $0.85 \pm 0.039^{\mathrm{b}}$ & $1.06 \pm 0.069^{\mathrm{c}}$ & $0.73 \pm 0.022^{\mathrm{a}}$ \\
FCR & $2.91 \pm 0.25^{\mathrm{bc}}$ & $3.13 \pm 0.08^{\mathrm{b}}$ & $2.58 \pm 0.08^{\mathrm{b}}$ & $2.02 \pm 0.03^{\mathrm{a}}$ & $3.05 \pm 0.06^{\mathrm{c}}$ \\
PER & $1.23 \pm 0.09^{\mathrm{ab}}$ & $1.14 \pm 0.07^{\mathrm{a}}$ & $1.38 \pm 0.04^{\mathrm{b}}$ & $1.75 \pm 0.03^{\mathrm{c}}$ & $1.16 \pm 0.06^{\mathrm{a}}$ \\
NPU (\%) & $18.53^{\mathrm{a}}$ & $17.71^{\mathrm{a}}$ & $19.72^{\mathrm{a}}$ & $26.39^{\mathrm{b}}$ & $16.66^{\mathrm{a}}$ \\
\hline
\end{tabular}

The data are mean \pm SE. Values bearing different superscripts in a row differ significantly $(\mathrm{p}<0.05)$. SGR: Specific growth rate; FCR: Feed conversion ratio; PER: Protein efficiency ratio, NPU: Net protein utilisation. Average initial body weight ( $\mathrm{g}$ ) of the fingerlings was $5.25 \pm 0.2$

Table 5. Hemoglobin and biochemical constituents of the blood of L. rohita fingerlings fed feeds containing different level of mahua oil cake for 90 days

\begin{tabular}{|c|c|c|c|c|c|}
\hline Attributes & $\mathrm{F} 1(0 \% \mathrm{MOC})$ & F2 (10\% MOC) & $\mathrm{F} 3(20 \% \mathrm{MOC})$ & F4 (30\% MOC) & F5 (40\% MOC) \\
\hline Hemoglobin $\left(\mathrm{g} \mathrm{dl}^{-1}\right)$ & $7.85 \pm 0.23^{\mathrm{a}}$ & $7.91 \pm 0.33^{\mathrm{a}}$ & $7.77 \pm 0.27^{\mathrm{a}}$ & $9.23 \pm 0.03^{b}$ & $7.69 \pm 0.05^{\mathrm{a}}$ \\
\hline Glucose (mg dl-1 $)$ & $55.06 \pm 1.7^{\mathrm{d}}$ & $42.67 \pm 1.3^{\mathrm{b}}$ & $46.96 \pm 1.5^{\mathrm{c}}$ & $72.98 \pm 2.3^{\mathrm{e}}$ & $37.60 \pm 1.1^{\mathrm{a}}$ \\
\hline Protein $\left(\mathrm{g} \mathrm{dl}^{-1}\right)$ & $3.84 \pm 0.02^{\mathrm{a}}$ & $3.96 \pm 0.05^{b}$ & $4.08 \pm 0.03^{b}$ & $5.12 \pm 0.06^{\mathrm{c}}$ & $3.75 \pm 0.01^{\mathrm{a}}$ \\
\hline Albumin $\left(\mathrm{g} \mathrm{dl}^{-1}\right)$ & $2.39 \pm 0.03^{\mathrm{a}}$ & $2.35 \pm 0.05^{\mathrm{a}}$ & $2.40 \pm 0.03^{\mathrm{a}}$ & $2.34 \pm 0.05^{\mathrm{a}}$ & $2.32 \pm 0.03^{\mathrm{a}}$ \\
\hline Globulin $\left(\mathrm{g} \mathrm{dl}^{-1}\right)$ & $1.45 \pm 0.02^{\mathrm{a}}$ & $1.61 \pm 0.02^{\mathrm{b}}$ & $1.68 \pm 0.03^{b}$ & $2.78 \pm 0.03^{\mathrm{c}}$ & $1.62 \pm 0.01^{\mathrm{b}}$ \\
\hline Triglyceride $\left(\mathrm{mg} \mathrm{dl}^{-1}\right)$ & $302.74 \pm 7.32$ & $298.99 \pm 3.22$ & $296.54 \pm 2.67$ & $295.85 \pm 2.03$ & $299.68 \pm 1.18$ \\
\hline Cholesterol (mg dl $\left.{ }^{-1}\right)$ & $186.41 \pm 1.73^{\mathrm{b}}$ & $175.93 \pm 1.32^{\mathrm{ab}}$ & $182.81 \pm 0.66^{\mathrm{b}}$ & $211.28 \pm 0.35^{\mathrm{c}}$ & $167.42 \pm 0.24^{\mathrm{a}}$ \\
\hline SGOT $\left(\mathrm{u} \mathrm{l}^{-1}\right)$ & $148.63 \pm 2.17^{\mathrm{a}}$ & $152.74 \pm 1.03^{\mathrm{a}}$ & $156.77 \pm 0.53^{\mathrm{a}}$ & $159.23 \pm 0.52^{\mathrm{a}}$ & $219.16 \pm 2.34^{b}$ \\
\hline $\operatorname{SGPT}\left(\mathrm{u} \mathrm{l}^{-1}\right)$ & $24.63 \pm 0.12^{\mathrm{a}}$ & $27.16 \pm 1.51^{\mathrm{a}}$ & $28.64 \pm 1.08^{\mathrm{a}}$ & $26.71 \pm 1.67^{\mathrm{a}}$ & $39.64 \pm 1.60^{\mathrm{b}}$ \\
\hline
\end{tabular}

The data are mean \pm SE. Values bearing different superscripts in a row differ significantly $(\mathrm{p}<0.05)$. SGOT: serum glutamic oxaloacetic transaminase; SGPT : serum glutamic pyruvic transaminase 
SGOT and SGPT levels among groups F1 - F4 ( $>>0.05)$, but both SGOT and SGPT showed significantly higher value $(\mathrm{p}<0.05)$ in $\mathrm{F} 5$.

\section{Discussion}

The proximate composition of mahua oil cake and the toxic principle present in it have been reported by earlier workers (Singhaland Mudgal, 1984; Singh and Singh, 1991; Siddiqui et al., 2004; and Chaudhary et al., 2015). The crude protein content of MOC has been reported in the range of $19-30 \%$ and it is rich in many essential amino acids (Shanmugasundaram and Venkataraman, 1985; Ramadan et al., 2016). Considering the fairly good amino acid profile of MOC, Singhal and Mudugal (1984) opined that MOC is comparable with GNOC except for cysteine. They also recorded higher levels of essential amino acids like lysine, valine, methionine, isoleucine and leucine in MOC compared to GNOC. The fatty acid profile of MOC has been studied in detail by several workers (Marikkar and Yanty, 2012; Kulkarni et al., 2013; Munasinghe and Wansapala, 2015; Ramadan et al., 2016). They reported that the seed of mahua in different climatic conditions contains fat in the range of $40-54 \%$ which is in the form of oil at ambient temperature. The total saturated and unsaturated fatty acid content varied from 40-47 and $50-53 \%$ respectively, dominated by palmitic, stearic, oleic and linoleic acids. In the present study, the proximate composition of MOC was as follows: crude protein $24 \%$, crude lipids $9 \%$, saturated fatty acids $45 \%$ and unsaturated fatty acids $49 \%$ which corroborates the observations of earlier workers. The anti-nutrient factors of MOC have been studied in detail in the recent past by Yadav et al. (2012), Mishra and Pradhan (2013), Verma et al. (2014) and Chaudhuri et al. (2015). They found saponin as the major factor with flavonoids, glycosides, tannin and alkaloids. In the present study, all these anti-nutrient factors were detected by qualitative test. Limited literature is available on the use of MOC in ruminant feed. Incorporation of raw MOC as one of the feed ingredients at $10-20 \%$ in cattle gives significantly higher growth performance (Jakhmola et al., 1987; Tiwari et al.,1996; Singh et al., 2011; Patil et al., 2013; Jacob et al., 2015). No literature is available on the use of MOC as feed ingredient for fish feed. Therefore, we are compelled to compare the findings of this experiment with the available literature on ruminants. In the present experiment, MOC was incorporated in the diets at 10, 20,30 and $40 \%$ by partially replacing GNOC and rice bran. MOC incorporation at 20\% (F3) and 30\% (F4) resulted in better SGR (0.85 and 1.06), PER (1.38 and 1.75) and NPU (19.72 and 26.39). Similarly, the FCR was lowest (2.02) at 30\% level of incorporation. Hence, incorporation of $30 \%$ MOC not only yielded significant growth performance and least FCR, but also replaced the conventional ingredients like GNOC and rice bran at 120 and $180 \mathrm{~g} \mathrm{~kg}^{-1}$ respectively. Ojha et al. (2013) and Jacob et al. (2015) reported better growth of crossbred calves with $10 \%$ of MOC incorporation. Tiwari et al. (1996) incorporated raw MOC at 20\% level in the crossbred calves without affecting body weight gain. Considering the growth and economic gain, Khaing et al. (2015) opined that MOC could be incorporated in commercial concentrate for goat at 30\% without any adverse effect on their performance. Although no literature is found on the incorporation of MOC in fish feed, Francis et al. (2005) reported that quillaja saponin acts as a growth promoter when incorporated in the fish feed. Recently, Serrano (2013) observed that by adding saponin to the feed, the average body weight of common carp increased significantly. Francis et al. (2002) opined that dietary saponin increases permeability of intestinal membrane to the digested dietary components, thereby increasing the feed utilisation efficiency. Serrano et al. (1998) expressed the view that dietary quillaja saponin could significantly increase the activity of amylase and trypsin in the gut as well as lactate dehydrogenease in the liver of carp. In the present study, the mahua saponin would have hastened the absorption of nutrient macromolecules across the gut and that might have optimised at $30 \%$ level of MOC incorporation. Inclusion of MOC at the next higher level (40\%) reduced fish growth significantly. Chein et al. (2011) reported similar observation in Japanese flounder. In their experiment, enhanced growth was recorded in the feeding group where soybean saponin was incorporated at $0.8 \mathrm{~g} \mathrm{~kg}^{-1} \mathrm{feed}$, but growth was reduced at the next higher level of incorporation.

Fish receiving feed 4 (F4), which contained $30 \%$ MOC, showed significantly better hemoglobin $\left(9.23 \mathrm{~g} \mathrm{dl}^{-1}\right)$, globulin $\left(2.78 \mathrm{~g} \mathrm{dl}^{-1}\right)$ and cholesterol $\left(211.28 \mathrm{mg} \mathrm{dl}^{-1}\right)$ levels in blood than the other dietary groups $(p<0.05)$. These hematological parameters reduced significantly $(p<0.05)$ when incorporation level of MOC was $40 \%$. Increased SGOT and SGPT in serum is a sign of unhealthy liver. SGOT and SGPT in the present study were similar ( $>0.05)$ in all the feeding groups up to $30 \%$ incorporation of MOC. These two parameters significantly increased (219.16 and $39.64 \mathrm{u} \mathrm{l}^{-1}$ respectively) when incorporation level was enhanced to $40 \%$, which could be considered as another indication of incorporation limit. Francis et al. (2002) in their review discussed about hypoglycemic role of dietary saponin. They suggested that the hypoglycemic action may be due to the inhibition of glucose transport across the brush border of the small intestine. The drastic drop in blood glucose level with the diet containing $40 \%$ MOC in the present study may be due to higher dietary saponin. In India, use of MOC as 
a piscicide in carp culture ponds is a common practice. The fish mortality occurs due to hemolytic effect of saponin, absorbed through gill. Das et al. (2013) reported the details of hematological alteration and morbidity in catla, rohu and mrigal with the application of MOC at 250 ppm in water. Rajput and Gaur (2015) recorded increased liver and muscle protein in Clarias batrachus when treated with lethal and sublethal doses of MOC, which they described as the sign of stress. In the present study, MOC when administered through feed in limited quantity did not manifest any toxic effect. Perhaps this is the first study which reveal that there is scope to use MOC in carp feed as a non-conventional ingredient not only to replace the conventional ingredient, but also as a growth promoter.

\section{Acknowledgements}

Authors are grateful to Dr. P. Jayasankar, former Director, ICAR-Central Institute of Freshwater Aquaculture (ICAR-CIFA), Kausalyaganga, Bhubaneswar, India for providing all required facilities to conduct the experiment.

\section{References}

Allain, C. C., Poon, L. S., Chan, C. S. G., Richmond, W. and $\mathrm{Fu}$, P. C. 1974. Enzymatic determination of total serum cholesterol. Clinical Chem., 20: 470-475.

AOAC 1990. Official method of analysis. Association of Official Analytical Chemists, Arlington, V. A, USA, p. 69-78.

APHA 1989. Standard methods for the examination of water and waste water, $17^{\text {th }}$ edn. American Public Health Association, Washington D. C., 1268 pp.

Barman, B. K. and Karim, M. 2007. Analysis of feeds and fertilisers for sustainable aquaculture development in India. In: Hasan, M. R., Hecht, T., De Silva, S. S. and Tacon, A. G. J. (Eds.), Study and analysis of feeds and fertilisers for sustainable aquaculture development. FAO Fisheries Technical Paper No. 497, Food and Agriculture Organisation, Rome, p. 113-140.

Chaudhary, A., Bhandari, A., Pandurangan, A. and Sameksha Koul 2015. Madhuca indica (Sapotaceae): An overview. Int. J. Pharm. Sci. Lett., 5: 539-545.

Chein, W., Ai Q., Mai, K., Xu, W., Liufu, Z., Zhang, W. and Cai, Y. 2011. Effects of dietary soybean saponins on feed intake, growth performance, digestibility and intestinal structure in juvenile Japanese flounder (Paralichthys olivaceus). Aquaculture, 318: 95-100.

Christie, W. W. 1982. Lipid analysis: Isolation, separation identification and structural analysis of lipids, Pergamon Press, Oxford, UK.

Daniel, N. 2016. Neem seed cake (NSC) as fish feed ingredient: opportunities and constraints. Int. J. Fish. Aquat. Stud., 4: 20-23.
Dash, G., Alam, S. K. S., Sahoo, S. and Panigrahi, A. K. 2013. Effect of mahua oil cake (MOC) on blood parameters of carps; Catla catla, Labeo rohita, Cirrhinus mrigala. Asian Aca. Res. J. Mult., 1:211-228.

Duncan, D. B. 1955. Multiple range and multiple F tests. Biometrics, 11: 1-42.

Evans, W. C. 2000. Trease and evan pharmacology, $14^{\text {th }}$ edn., WB Saunders Company Ltd., p. 224-293.

Folch, A. C., Leeds, M. and Sloane-Stanley, G. M. 1957. A simple method for isolation and purification total lipids from animal tissues. J. Biol. Chem., 226: 497-509.

Feedpedia. 2016. Mahua (Madhuca longifolia). Feedpedia a programme by INRA, CIRAD, AFZ and FAO, http:// www.feedipedia.org/node/Last updated on 16 September 2016 (Accessed 28 January 2017).

FAO 2010. The state of world fisheries and aquaculture. FAO Fisheries and Aquaculture Department, Food and Agriculture Organisation, Rome, Italy.

Francis, G., Kerem, Z., Makkar, H. P. and Becker, K. 2002. The biological action of saponins in animal systems: a review. Brit. J. Nutr., 88: 587-605.

Francis, G., Makkar, H. P. S. and Becker, K. 2005. Quillaja saponins - a natural growth promoter for fish. Anim. Feed Sci. Technol., 121: 147-157.

Harbone, J. B. 1998. Phytochemical methods - A guide to modern techniques of plant analysis. Champman and Hall, London, p. $182-190$.

Hasan, M. R., Hecht, T., De Silva, S. S. and Tacon, A. G. J. 2007. Study and analysis of feeds and fertilisers for sustainable aquaculture development. FAO Fisheries Ttechnical Paper No. 497, Food and Agriculture Organisation, Rome, $510 \mathrm{pp}$.

Jacob, A. B., Singh, P. and Verma, A. K. 2014. Effect of supplementation of deoiled mahua seed cake on the growth performance and blood biochemical parameters of crossbred calves during recovery period of infection from Fasciola gigantica. Anim. Nutr. Feed Techn., 14: 161-168.

Jacob, A. B., Singh, P. and Verma, A. K. 2015. Effect of feeding deoiled mahua (Bassia latifolia) seed cake on the growth performance, digestibility and balance of nutrients in crossbred calves during prepatent period of Fasciola gigantica infection. J. Anim. Physiol. Anim. Nutr. (Berl.), 99: 299-307.

Jakhmola, R. C., Sharma, V. and Punj, M. L. 1987. Limitations in the use of mahua seed cake in animal feeding - a review. Int. J. Anim. Sci., 2: 113-126.

Jayasree, B., Harishankar, N. and Rukmini, C. 1998. Chemical composition and biological evaluation of mahua flowers. J. Oil Technol. Ass., 30: 170-172.

Khaing, M., Aung, H. M. T., Mu., K. S., Aung, A. and Ngwe, T. 2015. Effect of madhuca seed cake replacement in 
concentrate mixture on digestibility and nitrogen utilisation of goat. Global J. Anim. Sci. Res., 3: 603-608.

Kulkarni, P. S., Sharanappa, G. and Ramesh, M. R. 2013. Mahua (Madhuca indica) as a source of biodiesel in India. Int. J. Sci. Eng. Res., 4: 2319-2328.

Lenka, S., Giri, S. S and Paul, B. N. 2010. Nutrient digestibility and gastro-intestinal enzyme activity of Cyprinus carpio (var. communis) fingerlings fed water washed neem seed cake incorporated diets. Indian J. Anim. Sci., 80: 96-100.

Manomaitis, L. 2009. Improving South-east Asian aquaculture through feeds and technology. Proceeding of the $17^{\text {th }}$ Annual ASAIM SEA Feed Technology and Nutrition Workshop, Vietnam, p. 15-19.

Marikkar, J. M. N. and Yanty, N. A. M. 2012. Seed fat from Madhuca longifolia as raw material for halal alternative fats. Borneo Sci., 31: 84-93.

Mishra, S. and Pradhan, S. 2013. Madhuca lonigfolia (Sapotaceae): A review of its traditional uses and nutritional properties. Int. J. Human. Social Sci. Invention, 2: 30-36.

Munasinghe, M. and Wansapala, J. 2015. Study on variation in seed morphology, oil content and fatty acid profile of Madhuca longifolia grown in different agro-climatic zones in Sri Lanka. Sci. Res., 3: 105-109.

Ojha, B. K., Singh, P., Verma, A. K., Chaturvedi,V. B. and Kumar, A. 2013. Effect of feeding of deoiled mahua seed cake and guar meal on blood biochemical, immune response and urinary purine derivatives in crossbred calves. Anim. Nutr. Feed Tech., 13: 69-78.

Patil, A. K., Chaturvedi, V. B., Awase, M., Shrikant, B. K. and Soni, Y. K. 2013. Influence of mahua seed cake on serum profile in crossbred calves. Livestock Res. Int., 1: 29-33.

Rajput, V. and Gaur, R. 2015. Toxicological study on Clarias batrachus caused by croton and mahua extract. J. Pharmacogn. Phytochem., 3: 32-34.

Ramadan, M. F., Mohdaly, A. A., Assiri, A. M., Tadros, M. and Niemeyer, B. 2016. Functional characteristics, nutritional value and industrial applications of Madhuca longifolia seeds: an overview. J. Food Sci. Technol., 53: 2149-2157.

Rath S. C., Nayak, K. C., Mohanta, K. N., Pradhan, C., Rangacharyulu, P. V., Sarkar, S. and Giri, S. S. 2014. Nutritional evaluation of rain tree (Samanea saman) pod and its incorporation in the diet of rohu (Labeo rohita Hamilton) larvae as a non-conventional feed ingredient. Indian J. Fish., 61: 105-11.
Serrano, A. Jr., Focken, U., Francis, G., Makkar, H. P. S. and Becker, K. 1998. Effects of Quillaja saponins on the activity of selected gut and liver enzymes of carp, Cyprinus carpio. In: Jarayabhand, P., Chaitanawisuti, N., Sophon, A., Kritsanapuntu, A., and Panichpol, A. (Eds.), Fifth Asian Fisheries Forum, Proceedings of the International Conference on Fisheries and Food Security, Asian Fisheries Society, Manila, Philippines, 204 pp.

Serrano, A. Jr. 2013. Effects of Quillaja saponins on growth, feed efficiency, digestive enzyme activities and metabolism of common carp (Cyprinus carpio). Aquac. Nutr., 19: 468-474.

Shanmugasundaram, T. and Venkataraman, L. V. 1985 Nutritional evaluation of ethanol extracted Madhuca (Mdhuca butyraceae) seed flour. J. Sci. Food Agric., 36: 1189-1192.

Siddiqui, Bina S., Khan, S., Kardar, M. Nadeem and Aslam, H. 2004. Chemical constituents from the fruits of Madhuca latifolia. Helvita Chimica Acta, 87: 1194-1201.

Singh, A. and Singh, I. S. 1991. Chemical evaluation of mahua (Madhuca indica) seed. Food Chem., 40: 221-228.

Singh, P., Verma, A. K., Jacob, A. B., Gupta, S. C. and Mehra, U. R. 2011. Haematological and biochemical changes in Fasciola gigantica infected buffaloes fed on diet containing deoiled mahua (Bassia latifolia) seed cake. J. Appl. Anim. Res., 39: 185-188.

Singhal, K. K. and Mudgal, V. D. 1984. Amino acid profile of some conventional and unconventional protein supplements. Indian J. Anim. Sci., 54 : 990 - 992.

Snedecor, G. W. and Cochran, W. 1967. Statistical methods, $6^{\text {th }}$ edn. Oxford and IBH Publishing Co., New Delhi, 593 pp.

Tiwari, D. P., Nema, R. K. and Chourasia, S. K. 1996. Nutritive evaluation of mahua (Madhuca indica) seed-cake in crossbred calves. Indian J. Anim. Sci., 66: 304-306.

Verma, N., Jha, K. K., Kumar, U., Deepak, K., Singh, N. K., Singh, A. K. and Sharma, R. 2014. Biological properties, phytochemistry and traditional uses of Mahua (Madhuca longifolia): A review. Int. J. Adv. Res. Innovation, 2: 630-638.

Yadav, P., Singh, D., Mallik, A. and Nayak, S. 2012. Madhuca lonigfolia (sapotaceae): a review of its traditional uses, phytochemistry and pharmacology. Int. J. Biomedical Res., 3: 291-305. 